\title{
Indonesian Islamic Studies: Selected Dissertation Bibliography I980-1999
}

\author{
M. Endy Saputro \\ IAIN Surakarta \\ email: endysa@gmail.com
}

Continuing the previous editions, this bibliography presents dissertations produced mainly from universities in Australia, America, and Canada. Not only dissertations, some important theses are also featured in this bibliography. The period 1980-1999 is a crucial period in the process of Indonesian Islamic studies. Since 1990 the project of sending bachelor graduates to continue their master to McGill University resulted in Indonesian Islamic studies master theses produced by this universities. On the one hand, this theses can be used as an evidence that Indonesian scholars were able to "introduce" Indonesian Islam abroad; on the other hand, this introduction focuses on leaders thought - which is then dominated the pattern of Islamic studies in Indonesian Islamic higher education institutions. In comparison, dissertation/thesis from the universities in the United States and Australia shows notable interesting assumption that during that period the scholars whose background are Islamic studies tend to produce theological-doctrinal dissertation/thesis as well as that of leaders-thought; while scholars with social and cultural background tend to review Islam from the attending problems in society. 
Dhofier, Zamakhsyari. 1980. "The Pesantren Tradition: a Study of the Role of the Kyai in the Maintenance of the Traditional Ideology of Islam in Java," Dissertation. Australian National University.

Supratignyo, Titi. 1980. "A Study of Alternative Schooling in Indonesia: the Muhammadiyah Schools in Central Java and Yogyakarta Region," Master Thesis, La Trobe University

Nakamura, Hisako. 1981. "A Study of the Dissolution of Marriage among Javanese Muslims, Master Thesis," Australian National University.

Mudzhar, M. Atho, 1981. "Religious Education and Politics in Indonesia: a Preliminary Study of Islamic Education and Politics, 1966-1979," Master Thesis, The University of Queensland, School of Social Science

Adimihardja, Kusnaka, 1983. "Generations from Banten: a Wandering Spiritual Leader and His Followers in West Java," Master Thesis, Australian National University.

Maarif, A. S. 1983. "Islam as the Basis of the State: a Study of the Islamic Political Ideas as Reflected in the Constituent Assembly Debates in Indonesia," Dissertation, University of Chicago.

Morris, E. E. 1983. "Islam and Politics in Aceh: a Study of CenterPeriphery Relations in Indonesia," Dissertations. Cornell University.

Adamson, Andrew F. 1984. "Religion and State in New Order Indonesia, 1977-1979," Master Thesis, University of Melbourne.

Takeshi, Ito, 1984. "The World of the Adat Aceh: a Historical Study of the Sultanate of Aceh," Dissertation. Australian National University. Research School of Pacific and Asian Studies

Gregory Riddell, Peter. 1984. "Abd Al-Ra'uf Al-Singkili’s Tarjuman AlMustafid: a Critical Study of His Treatment of Juz' 16," Master Thesis. Australian National University.

Yatim, O. B. M. 1985. "Batu Aceh: a Study of 15th - 19th Century Islamic Gravestones in Peninsular Malaysia," Dissertation. University of Durham.

Woodward, M. R. 1985. "The Shari'ah and the Secret Doctrine: Muslim Law and Mystical Doctrine in Central Java," Dissertation, University of Illinois. 
Shiraishi, T. 1986. "Islam and Communism: an Illumination of the People's Movement in Java, 1912-1926," Dissertation. Cornell University.

Patty, Semuel Agustinus. 1986. “'Aliran Kepercayaan” a Socio-Religious Movement in Indonesia," Dissertation. Washington State University.

Huehne, Eva, 1987. "Marxism and Religion: the Ideological Polemic: a Study of the Limitations of Orthodox Marxism with Reference to Relations between the PKI and Islamic Groups in Indonesia 1955-1965," Thesis BA. Griffith University

Er, L. M. 1987. "The Introduction and Expression of Islam and Christianity in the Cultural Context of North Central Java (Indonesia)," Dissertation. Fuller Theological Seminary, School Of World Mission

Tambunan, D. 1987. "A Program for Training in Personal Christian Witnessing to the Muslim of Indonesia," Dissertation. Andrews University.

Aidid, Hasyim. 1987. "Islamic Leaders' Attitudes towards Family Planning in Indonesia (1950's - 1980's)," Master Thesis, Australian National University

Bailey, Douglas J, 1987. "Rural Islam in Sundanese Java: a Cultural Interpretation of Peasant Resistance," Dissertation, University of Sydney.

Aidid, Hasyim, 1987. “Islamic Leaders' Attitudes towards Family Planning in Indonesia (1950's - 1980's), Master Thesis, Australian National University.

Mansurnoor, L. A. 1987. "Ulama, Villagers and Change Islam in Central Madura," Dissertation. McGill University.

Seino, K. 1988. "Islamization of Java: Missiological Analysis," Master Thesis. Fuller Theological Seminary School of World Mission

Turmudi, Endang, 1990. "Modernisation, Religion and Voting Behaviour: a Study of Islamic Reassertion and Political Change in Indonesia," Master Thesis, Flinders University of S. Aust.

Mudzhar, M. A. 1990. ““'Fatwa”s' of the Council of Indonesian Ulama: a study of Islamic Legal Thought in Indonesia, 1975-1988," Dissertation. University of California 
Usman, Sunyoto, 1991, “Local Elites and Development: a Case Study of the Role of Local Elites in the Implementation of Development Projects in Three Santri East Javanese Villages," Dissertation, Flinders University of S. Aust.

Patji, Abdul Rachman, 1991." The Arabs of Surabaya: a Study of Sociocultural Integration," Master Thesis, Australian National University

Budiwanti, Erni, 1991. "The Crescent Behind the Thousand Holy Temples: an Ethnographic Study of the Minority Muslims of Pegayaman, North Bali," Master Thesis, Monash University.

Syamsuddin, M. Sirajuddin. 1991. "Religion and Politics in Islam: the Case of Muhammadiyah in Indonesia's New Order," Dissertation. University of California.

Waney, R. A. 1991. "Missiological Dimensions in Interreligious Marriages between Christians and Muslims in Indonesia," Dissertation, Fuller Theological Seminary, School of World Mission.

Schwede, L. K. 1991. "Family Strategies of Labor Allocation and DecisionMaking in a Matrilineal, Islamic Society: the Minangkabau of West Sumatra, Indonesia," Dissertation, Cornell University.

Goksoy, I. H. 1991. "Dutch Policy towards Islam in Indonesia, 19451949," Dissertation. University of London, School of Oriental and African Studies.

Surbakti, R. A. 1991. "Interrelation between Religious and Political Power under New Order Indonesia," Dissertation. Northern Illinois University.

Truna, D. S. 1992. "Islam and Politics under the "New Order" Government in Indonesia, 1966-1990," Master Thesis, McGill University.

Azra, A. 1992. "The Transmission of Islamic Reformism to Indonesia: Networks of Middle Eastern and Malay-Indonesian "Ulama" in the Seventeenth and Eighteenth Centuries," Dissertation. Columbia University.

Hadi, A. 1992. "Aceh and the Portuguese: a Study of the Struggle of Islam in Southeast Asia 1500 - 1579," Master Thesis. McGill University. 
Mulyati, S. 1992. "Sufism in Indonesia: an Analysis of Nawawi al-Banteni's "Salalim al-Fudala,", Master Thesis. McGill University

Latif, H. A. 1992. "Persatuan Ulamā Seluruh Aceh (PUSA): Its Contributions to Educational Reforms in Aceh," Master Thesis, McGill University.

Jainuri, A. 1992. "The Muhammadiyah Movement in Twentieth-Century Indonesia: a Socio-Religious Study," Dissertation. McGill University.

Strain, John, 1992. "Nationalism and the Struggle in Aceh for an Independent Indonesia," Master Thesis. University of Sydney.

Said, N. 1992. "Al-Ghazali's Works and Their Influence on Islam in Indonesia," Master Thesis. McGill University.

Abdul Hakim, Sudarnoto. 1993. "The Partai Persatuan Pembangunan: the Political Journey of Islam under Indonesia's New Order (19731987)," Master Thesis. McGill University.

Bakti, A. M. F. 1993. "Islam and Nation Formation in Indonesia," Dissertation. McGill University.

Auni, L. 1993. "The Decline of the Islamic Empire of Aceh (1641-1699)," Master Thesis. McGill University.

Furchan, A, 1993. "Developing Pancasilaist Muslims: Islamic Religious Education in Public Schools in Indonesia," Master Thesis, La Trobe University.

Whalley, L. A. 1993. "Virtuous Women, Productive Citizens: Negotiating Tradition, Islam, and Modernity in Minangkabau, Indonesia," Dissertation. University of Illinois at Urbana-Champaign.

Rifai, N. 1993. "Muslim Women in Indonesia's Politics: an Historical Examination of the Political Career of Aisyah Aminy," Master Thesis. McGill University.

Effendy, B. 1994. "Islam and the State: the Transformation of Islamic Political Ideas and Practices in Indonesia," Dissertation. The Ohio State University.

Ali, Fachry, 1994. "The Revolts of the Nation-State Builders: a Comparative Study of the Acehnese Darul Islam and the West Sumatran PRRI Rebellions (1953-1962)," Master Thesis, Monash University. 
Anshori, Ibnu. 1994. "Mustafa Kemal and Sukarno: a Comparison of Views Regarding Relations Between State and Religion," Master Thesis. McGill University.

Amiruddin, M. Hasbi. 1994. "The Response of the 'Ulama' Dayah to the Modernization of Islamic Law in Aceh". Master Thesis. McGill University.

Cheng Yeoh, Siok. 1994. "Umara-Ulama-Ummah Relations and Pesantrens in Aceh Province, Indonesia: a Study of the Challenges to the Authority of a Traditionalist Kiyai". Dissertation. University of Washington.

Zulkifli, 1994. "Sufism in Java: the Role of the Pesantren in the Maintenance of Sufism in Java," Master Thesis. Australian National University.

Subandi, 1994. "A Psychological Study of Religious Transformation among Moslems Who Practice Dzikir Tawakkal," Master Thesis. Queensland Research Thesis, University of Technology.

Lubis, N. A. F. 1994. "Islamic Justice in Transition: a Socio-legal Study of the Agama Court Judges in Indonesia," Dissertation. University of California.

Mandal, S. K. 1994. "Finding Their Place: a History of Arabs in Java under Dutch Rule, 1800-1942," Dissertation, Columbia University.

Makmur, Iizamudi. 1995. "Abul A'la Mawdudi's and Mohammad Natsir's View on Statehood: a Comparative Study," Master Thesis. McGill University.

Yusuf, Milhan. 1995. "Hamka's Method of Interpreting the Legal Verses of the Qur'an: a Study of His Tafsir-Al-Azhar," Master Thesis. McGill University.

Saby, Yusny. 1995. "Islam and Social Change: The Role of the Ulama in Acehnese Society," Dissertation. The Temple University.

Ismail, Faisal. 1995. "Islam, Politics and Ideology in Indonesia: a Study of Process of Muslim Acceptance of the Pancasila," Dissertation. McGill Unversity.

Shihab, Alwi. 1995. "The Muhammadiyah Movement and Its Controversy with Chistian Mission,” Dissertation. The Temple Graduate Board. 
Rifki Rosyad, 1995. "A Quest for True Islam : a Study of the Islamic Resurgence Movement among the Youth in Bandung, Indonesia," Master Thesis, Australian National University.

Jamhari, 1995. "To Visit a Sacred Tomb: the Practice of Ziarah to Sunan Tembayad's Resting Place in Klaten, Java," Master Thesis, Australian National University.

Barton, Gregory James. 1995. “The Emergence of Neo-Modernism: a Progressive, Liberal Movement of Islamic Thought in Indonesia : a Textual Study Examining the Writings of Nurcholish Madjid, Djohan Effendi, Ahmad Wahib and Abdurrahman Wahid, 19681980," Dissertation. Monash University.

Muhaimin, Abdul Ghoffur. 1995. "The Islamic Traditions of Cirebon : Ibadat and Adat among Javanese Muslims," Dissertation. Australian National University. Research School of Pacific and Asian Studies

Turmudi, Endang. 1996. "Struggling for the Umma: Changing Leadership Roles of Kiai in Jombang, East Java," Dissertation. Australian National University

Solahudin, Dindin, 1996. "Workshop for Morality: the Islamic Creativity of Pesantren Daarut Tauhid in Bandung, Java," Master Thesis, Australian National University.

Kim, Hyung-Jun. 1996. "Reformist Muslims in a Yogyakarta Village: the Islamic Transformation of Contemporary Socio-religious Life," Dissertation, Australian National University.

Adnan, Muhammad Akhyar, 1996. "An Investigation of Accounting Concepts and Practices in Islamic Banks: the cases of Bank Islam Malaysia Berhad and Bank Muamalat Indonesia," Dissertation, University of Wollongong.

Isnaeni, Hendrajaya. 1996. "The Javanese Mosque: a Regional Interpretation of Form and Mystical Concepts," Dissertation. University of Melbourne.

Tholkhah, Imam. 1996. "Recurrent Political Tensions in Rural Java : a Case Study of Madukoro Village," Dissertation. University of Sydney

Santosa, June Chandra. 1996. "Modernization, Utopia and The Rise of Islamic Radicalism in Indonesia". Dissertation. Boston University. 
Hamim, Thoha. 1996. "Moenawar Chalil's Reformist Thought: a Study of an Indonesian Religious Scholar". Master Thesis. McGill University.

Mardatillah, F. 1997. "Intellectual Responses to the Establishment of Ikatan Cendekiawan Muslim Indonesia (ICMI), 1990-1995," Master Thesis, McGill University.

Lukens-Bull, Ronald Alan. 1997. "A Peaceful Jihad : Javanese Islamic Education and Religious Identity Construction," Dissertation. Arizona State University.

Minhaji, Akh. 1997. "Ahmad Hasan and Islamic Legal Reform In Indonesia," Dissertation. McGill Unversity.

Ruswan. 1997. "Colonial Experience and Muslim Educational Reform: a Comparison of The Aligarh and The Muhammadiyah Movwments". Master Thesis. McGill University.

Sumukti, Sumastuti. 1997. "Gunungan The Javanese Cosmic Mountain," Dissertation. University of Hawaii.

Wan-Yusof, Wan Sabri. 1997. "Hamka's Tafsir Al-Azhar : Qur'anic Exegesis as a mirror of Social Change," Dissertation. The Temple University Graduate Board.

Sung, Back Eun. 1997. "How to Make Christ Known Among Education Muslim Sisters in Surabaya, Indonesia," Dissertation. United Theological Seminary.

Wagiman, Suprayetno. 1997. "The Moodernization of The Pesantren's Educational System to Meet The Needs of Indonesian Communities". Master Thesis. McGill University.

Siapno, Jacqueline Aquino. 1997. "The Politics of General, Islam and National-state in Aceh, Indonesia: a Historical Analitysis of Power, Co-optation and Resistance," Dissertation. University of California, Berkeley.

Wijoyo, Alex Soesilo. 1997. "Shaykh Nawawi of Banten : Texts, Authority, and The Gloss Tradition”. Dissertation. Columbia University.

Jainuri, Achmad. 1997. “The Formation of The Muhammadiyah's Ideology". Master Thesis. McGill University, Montreal. 
H. Abd. Rachman. 1997. "The Pesantren Architects and their SocioReligious Teachings," Dissertation. University of California, Los Angeles.

Budiwanti, Erni. 1997. Religion of the Sasak: an Ethnographic Study of the Impact of Islamisation on the Wetu Telu of Lombok," Dissertation. Monash University

Thontowi, Jawahir. 1997. "Law and Custom in Makasar Society: the Interaction of Local Custom and the Indonesian Legal System in Dispute Resolution,” Dissertation, University of Western Australia.

Frazer, Neil Douglas, 1997. "Healing and Religious Traditions in West Java: an Exploration of the Development and Adaptation of the Healing Knowledge and Practice of a Syncretist Muslim Sundanese Healer," Dissertation. University of Newcastle

Lukito, R. 1997. "Islamic Law and Adat Encounter: The Experience of Indonesia," Master Thesis," McGill University

Drakeley, S. M, 1998. "Islam in Indonesian Politics, 1965-1971 : the Transition to the New Order," Dissertation. University of Sydney

Gallen, Ben. 1998. "Muslim Intellectual Responses to Modernization: the Emergemce of ICMI," Master Thesis. Monash University.

Fealy, Greg. 1998. "Ulama and Politics in Indonesia : a History of Nahdlatul Ulama, 1952-1967,” Dissertation. Monash University.

van der Sterren, Anke, 1998. “'Kondom oke, kondomisasi no' : HIV/ AIDS Prevention Policy and Constructions of Sexual Morality in Indonesia, with Specific Reference to the Construction of Islamic Attitudes," Master Thesis, Australian National University.

Pramuka, Bambang Agus. 1998. "Accounting In Indonesia - A Study of the Ideological Influences on Western and Islamic Accounting Thought and Practices," Dissertation. University Of Hull.

Haris, Ahmad. 1998. "Innovation and Tradition in Islam: a Study on Bid'ah as an Interpretation of the Religion in the Indonesian Experience," Dissertation. Temple University.

Husni, Dardiri. 1998. "Jong Islamieten Bond: a Study of Amuslim Youth Movement in Indonesia During The Outer Colonial Era, $1924-$ 1942," Master Thesis. McGill University. 
Zaini, Achmad. 1998. "Kyai Haji Abdul Wahid Hasyim: His Contribution to Muslim Educational Reform and to Indonesian Nationalism During the Twentieth Century". Master Thesis. McGill University.

Ropi, Ismatu. 1998. "Muslim Responses to Christianity in Modern Indonesia," Master Thesis. McGill University Montreal.

Husni, Asna. 1998.'Philosophical and Sosiological Aspects of Da'wah: A Study of Dewan Dakwah Islamiyah Indonesia," Dissertation. Colombia University.

Mawardi, Ahmad Imam. 1998."Socio-Political Background of the Enactment of Kompilasi Hukum Islam Indonesia". Master Thesis. McGill University.

Hilmy, M. 1998. "Islam and Javanese Acculturation: Textual and Contextual Analysis of the Slametan Ritual," Master Thesis. McGill University.

Abdul Kadir, S. 1999. Traditional Islamic Society and the State in Indonesia: the Nahdlatul Ulama, Political Accommodation and the Preservation of Autonomy. Dissertation. The University of Wisconsin - Madison

Ryan, Bartholomew John. 1999."Alif Lam Mim Reconciling Islam, Modernity, and Tradition in a Indonesia Kampung." Dissertation. Harvard University Cambridge, Massachusetts.

M. Gade, Anna. 1999."'An Envy of Goodness Learning to Recite the Qur'an in Modern Indonesia." Dissertation. The University of Chicago.

Mclaren, Kristin. 1999.'Indonesians Muslims in Canada: Religion, Ethnicity and Identity." Dissertation. University of Ottawa.

Batubara, Chuzaimah. 1999. "Islam and Mystical Movements in PostIndependence Indonesia: Susila Budhi Dharma (Subud) and Its Doctrines.” Master Thesis. McGill University.

Hadi, Amirul. 1999. "Islam and State in Seventeenth Century Aceh." Dissertation. McGill University Montreal.

Sugiono, Sukiati. 1999. "Islamic Legal Reform in Twentieth Century Indonesia: a Study of Hazairin's Thought." Master Thesis. McGill University. 
Juhannis, Hamdan. 1999. "Mohamad Reom's Political Activities and Islamic Political Vision (1908-1983),"Master Thesis. McGill University Montreal.

Asy'ari, Su'aidi. 1999. “The Role of Muslim Groups in Contemporary Indonesian Nationalism: a Study of the Nahdlatul Ulama Under The New Order 1980s-1990s," Master Thesis. McGill University.

Kadir, Suzaina Abdul. 1999. "Traditional Islamic Society and the State in Indonesia: The Nahdlatul Ulama, Political Accommodation and the Preservation of Autonomy." Dissertation. University of Wisconsin-Madison.

Hasbullah, Moeflich, 1999. "The Making of Hegemony: Cultural Presentations of the Muslim Middle Class in Indonesian New Order Period," Master Thesis, Australian National University.

Kato, Hisanori. 1999. "Religion and Its Functions in Society: Islam and the Creation of a Democratic Civilised Society in Indonesia : with special attention to Nahdlatul Ulama, Muhammadiyah and Ikatan Cendekiawan Muslim se-Indonesia," Dissertation. University of Sydney

Sirozi, M.. 1999. "Politics of Educational Policy Production in Indonesia," Master Thesis. Monash University.

Sya'roni, M. 1999. “The Majlisul Islamil A la Indonesia (MIAI): Its Socioreligious and Political Activities (1937--1943)," Master Thesis, McGill University

Latif, Yudi. 1999. "On Secularisation and Islamisation in Indonesia: a Sociological Interpretation," Master Thesis. Australian National University 